\title{
Veidenbauma dzeja kā muzikālās daiḷrades katalizators
}

\author{
Ligita Ašme
}

\begin{abstract}
Kopsavilkums
Eduarda Veidenbauma 150. jubilejas gadā dažādos pasākumos bija redzams tas, cik viņa dzeja šķiet saistoša mūsdienu cilvēkiem. Liela daḷa no visu veidu akcijām bija saistītas ar dziesmām, kurās izmantota šì dzeja. Tas bija rosinājums pārskatīt Veidenbauma dzejas attiecības ar to muzikālo interpretāciju. Latviešu mūzikas vēstures pētniecībā ir maz līdzīgu precedentu. Veidojot pārskatu par dziesmām ar Veidenbauma dzeju, jāsaskaras ar nepietiekamu informāciju divu iemeslu dēḷ. Pirmkārt, senākām dziesmām melodiju autori nav zināmi, otrkārt, amatieru dziesmas ne vienmēr fiksētas notīs vai ierakstos. Tomēr izrādās, ka arī ar pieejamās informācijas daudzumu iespējams gūt zināmu pārskatu par šo dziesmu kopumu.

Var secināt, ka Veidenbauma dzeja salīdzinājumā ar viṇa nelielo dzejas korpusu ir proporcionāli daudz komponēta - gandrīz katrs otrais dzejolis. Virkne dzejol̦u - nevis vienu vai divas reizes, bet pat vairākkārt, piemēram, tik populārais dzejolis "Kā gulbji balti padebeši iet" mūzikā interpretēts vismaz septiņas reizes. Savukārt, iedzilịnoties secībā, kādā radušās dziesmas ar Veidenbauma dzeju, nākas pārskatīt vai visu latviešu mūzikas vēsturi, jo šis laikposms ir vairāk nekā simts gadus ilgs. Tāpēc te izpaužas ne tikai tas, kā un kāpēc tieši Veidenbauma dzeja izmantota dziesmās, bet arī tas, kāda kopumā bijusi dziesmu tekstu un melodiju attiecību dinamika dziesmas žanra attīstības gaitā. Tas ir papildu komponents ainavai, kuru atspoguḷo dziesmu kopums ar Veidenbauma dzeju.
\end{abstract}

Raksturvārdi: dziesma, dzejas interpretācija, dzejas muzikalitāte, sadzīves dziesmas.

Eduarda Veidenbauma dzejas interpretācijas mūzikā veido savā zin̄ā neparastu dziesmu kopumu - mazskaitlīgu, bet nozīmīgu. Viņa dzejas mantojums ir neliels. Literatūrkritikisis Guntis Berelis par to raksta:

No aptuveni simts sacerētajiem dzejoḷiem viņa dzīves laikā nav publicēts neviens (periodikā parādījās tikai daži raksti un tulkojumi). [..] Pirmā Veidenbauma dzejas publikācija parādījās tieši gadu pēc viņa nāves; pirmā grāmata - cenzūras izkropḷots dzejoḷu krājums - iznāca 
1896. gadā. Škiiet, neviens daudzmaz nozīmīgs literāts savas dzīves laikā nav bijis tik l,oti nezināms. ${ }^{1}$

Dziesmas ar Veidenbauma tekstiem radušās salīdzinoši ilgā laika nogrieznī - vairāk nekā simts gadu laikā, tāpēc atspoguḷo ne vien viņa dzejas rezonansi mūzikā, bet arī tendences latviešu dziesmas žanra attīstībā kopumā.

Vērtējot šo dziesmu autoru skaitu, jāņem vērā proporcija starp dzejoḷu un sacerēto dziesmu daudzumu, tāpēc iespēju robežās jāprecizē, kāds ir ar Veidenbauma dzeju sacerēto dziesmu apjoms. Šã pētījuma mērḳis nav bijis sastādīt pilnīgu to dziesmu sarakstu, kurās izmantota Veidenbauma dzeja. Vairāku iemeslu dēl tas var būt neprecīzs, taču kopējās ainas un tendenču iezīmēšanai ir pietiekami ar publiski pieejamo informāciju. Šì dziesmu kopuma īpatnība ir tāda, ka tā aizsākums ir tik sens, ka pirmo dziesmu melodiju autori nav identificējami. Tas saistīts ar oriǵ̣inālmelodiju trūkumu un sabiedrības attieksmi pret mūzikas autorību šo dziesmu rašanās laikā pirms simts un vairāk gadiem. Nekādi autortiesību ierobežojumi tolaik nepastāvēja.

Viena no dziesmām ar Veidenbauma vārdiem un nezināma autora melodiju ir līdz pat mūsdienām pazīstamā "Domāju es domas dziḷas". Dziesmas tips - sentimentālai zing̣gei līdzīga sadzīves dziesma - liecina, ka tā radusies 19. gadsimta beigās, 20. gadsimta sākumā, kad daudzas cittautu komponistu dziesmas Latvijā tika lokalizētas un dziedātas ar pielāgotiem tekstiem. Plašāk zināmais piemērs ir "Dažu skaistu ziedu" ar 1891. gadā publicētā Andrieva Niedras dzejoḷa tekstu. Arī to gadiem ilgi Latvijā dziedāja kā anonīma autora sadzīves dziesmu. Tikai Trešās atmodas laika publikācijās līdzās dziesmas nosaukumam parādījās arī mūzikas autora vārds, jo laika gaitā izdevies noteikt, ka te izmantotā melodija aizgūta no vācu komponista Franča Abta dziesmas Die Lilie / Schöne Silberblüte... ("Lilija / Skaistie sudrabainie ziedi..."). ${ }^{2}$

19. gadsimta beigās bija izplatīta arī otrāda parādība - latvisku tekstu pielāgošana pazīstamām cittautu melodijām, jo tolaik vēl bija ḷoti maz latviešu komponistu un maz oriǵināldziesmu. Tas atspogulojas, piemēram, Kaudzītes Matīsa stāstā par to, kā Jēkabs Pilsātnieks savus dzejoḷus nopūlējies pielāgot pazīstamām vācu komponistu melodijām:

Tolaik vēl nevarēja nekā runāt par savas tautas komponistu meldijām, bet tās nācās n,emt no ārpuses - no citu tautu mūzikas, un viṇās pēc mēra jeb šablona bij jāiegulda dziedamie teksti jeb "vārdi" it kā rūtīs jeb gleznas rāmjos. ${ }^{3}$

Šāda tipa "jaundziesmu" apzināšanai 80. gadu beigās pievērsušies Literatūras, folkloras un mākslas institūta Latviešu folkloras krātuves pētnieki, latvisko tekstu

1 Berelis, G. Latviešu literatūras vēsture. Rīga: Zvaigzne ABC, 1999. 34. lpp.

2 Nr. 7. Die Lilie. In: Baltischer Liederkranz. Erster und zweiter Teil: ausgewählte Lieder zum Gebrauch für den Gesangunterricht. Hrsg. von Johann Reinfeldt. Reval: Kluge, 1886.

3 Kaudzīte, M. Atminas no tautiskā laikmeta. Rīga: Zvaigzne ABC, 1994. 427. lpp. 
pielāgojumus pazīstamām melodijām dēvējot par literāras izcelsmes dziesmām. Tās vairākās publikācijās raksturojusi Māra Vīksna:

Latviešiem tās aizsākās ar Veco Stenderu - mūsu laicīgās literatūras dibinātāju, dabas, mīlas un filozofiskās dzejas aizsācēju. Ar Vecā Stendera dzeju varam sākt pētīt folklorizēšanās procesu - literatūras sacerējumu iekḷaušanos tautas mutvārdu tradīcijā, iegūstot folkloras funkciju. ${ }^{4}$

Māra Vīksna raksturo pētnieku aizsākto darbu Latviešu folkloras krātuvē pie šāda tipa dziesmu kataloga - tajā ietverto dziesmu tekstu autori ir, sākot no Gotharda Frīdriha Stendera un beidzot ar Pēteri Jurciṇu. Kā folklorizējušos Veidenbauma tekstus viņa nosauc trīs: "Domāju es domas dziḷas", "Tumsa un migla pasauli sedz" un "Nost reiz skumību metīšu tumšo". ${ }^{5}$

Ar nezināmu melodiju dziedāts arī Veidenbauma dzejolis "Mosties, mosties reiz, svabadais gars" 1905. gada revolūcijas laikā. ${ }^{6}$ Cīṇas dziesmu kopīga dziedāšana sapulcēs un demonstrācijās bijusi 1905. gada revolūcijas īpatnība. Taču, kā 2005. gadā bija lasāms laikrakstā "Diena", "ja šodien būtu iespēja pašķirstīt kādu 1905. gada dziesmu kladi, droši vien ne tikai autortiesību speciālistiem būtu interesanti atklāt, ka lielākajai daḷai tā laika dziesmu melodijas bija zagtas un tikai vārdi tapuši Latvijā". ${ }^{7}$ Ja atmiṇās par revolucionārajām dziesmām pieminēti to autori, tad biežāk tie ir tekstu autori, dzejnieki, nevis komponisti, piemēram, tēlniece Aleksandra Briede, stāstot par bērnību, atcerējusies, ka kopā ar vecākiem dziedātas toreiz populārās revolucionāru dziesmas: Eduarda Veidenbauma "Mosties, mosties reiz, svabadais gars", Jāņa Akuratera "Ar kaujas saucieniem uz lūpām", Raiṇa "Lauztās priedes" un citas. ${ }^{8}$ Veidenbauma tekstu "Mosties, mosties reiz, svabadais gars" kā dziedātu dziesmu vairākās publikācijās pieminējis arī vēsturnieks Alfrēds Bušenieks. ${ }^{9}$ Primārā nozīme tolaik bija tekstam, par to liecina, piemēram, kādreizējās folkloras kursa docētājas Mildas Losbergas sniegtais raksturojums:

Daudzām 1905. gada revolūcijas dziesmām bija savas meldijas. Piemēram, Raiṇa "Lauztās priedes" dziedāja ar J. Sproǵa meldiju, tāpat sava meldija bija "Marseljēzai", "Varšavjankai", "Sarkanajam karogam”. Bija arī tādas dziesmas, ko dziedāja pēc citu pazīstamu dziesmu

4 Vīksna, M. Tautasdziesma un tā sauktā ziṇǵge. Latvijas Vēstnesis, 1995, Nr. 96, 22. jūn., 6. lpp.

5 Vīksna, M. Ziṇgge un folklorizēšanās. Latvijas PSR Zinātṇu Akadēmijas Vēstis, 1987, Nr. 10, 59. lpp.

6 Losberga, M. 1905. gada revolucionārās dziesmas Latvijā. Karogs, 1955, Nr. 1, 116. lpp.

7 [B. a.] 1905. "Diena (speciālizlaidums)", 2005, 13. janv., 2. lpp.

8 Kārklina, G. Pa bērnības un jaunības takām. Karogs, 1976, Nr. 8, 134. lpp.

9 Bušenieks, A. Caur vētrām un negaisiem pavasaris nāca. Zvaigzne, 1976, Nr. 8, 2. lpp. 
meldijām, piemēram, "Uz cīṇu visi, kam brīvība svēta” dziedāja ar Baumaṇu Kārḷa meldiju dziesmai "Kā Daugava vaida". ${ }^{10}$

Dziesmu krājumos, kuri saglabājušies no 20. gadsimta sākuma, redzams, ka viens un tas pats teksts izmantots vairāku komponistu dziesmās, piemēram, Raina "Lauztās priedes" dziedātas gan kā šodien tik pazīstamā Emīla Dārziṇa kora kompozīcija, gan nu jau pilnīgi aizmirstā Jūlija Sproǵa dziesma, arī Jāņa Akuratera dzejolis "Ar kaujas saucieniem uz lūpām" atrodams nošu pierakstā kā Jūlija Sproǵa dziesma, taču līdz mūsdienām nonācis cits variants - Akuratera teksts ar nezināma autora melodiju. ${ }^{11}$ Tas l,auj pien,emt, ka arī Veidenbauma "Mosties, mosties reiz, svabadais gars" atkarībā no situācijas dziedāts, pielāgojot kādu aizgūtu, tolaik pazīstamu melodiju.

Revolucionāri noskaņoto latviešu sociāldemokrātu uzskatos 20. gadsimta sākumā parādās vēl kāds mūzikas anonimitātes pamatojums - revolucionārās dziesmas esot kolektīvas, piemēram, Linards Laicens rakstījis:

Tagad vairs mēs daudz nejautājam, kas ir dziesmas autors, kas viņai devis melodiju, bet prasām, lai dziesma būtu strādniecību izteicoša un virzoša. Lai dziesmai būtu mērḳapzināta nozīmība. Vispār populārāko strādnieku cīnas dziesmu autori un komponisti masām nav zināmi, kaut gan pašas dziesmas pazīst katrs strādnieka bērns. Strādnieku dziesma ir kolektīva. ${ }^{12}$

Senākā dziesma ar Veidenbauma dzeju, kuras mūzikas autors ir droši zināms, ir Jān,a Zālǐša "Kā gulbji balti padebeši iet", kuru viņš komponējis studiju laikā Pēterburgas Konservatorijā 1905.-1906. gadā. ${ }^{13}$ Tādējādi laikposms, kurā sacerētas dziesmas ar Veidenbauma vārdiem, sācies līdz ar 19. un 20. gadsimta miju (bet pilnīgi droši - no 1905.-1906. gada) un sniedzas līdz mūsdienām, tātad ilgst krietni pāri par simts gadiem.

Apzinot ar Veidenbauma dzeju komponētās dziesmas, izveidots saraksts ar vairāk nekā trīsdesmit mūzikas autoriem. Apmēram puse no tiem ir profesionāli komponisti, puse - amatieri. Tas nozīmē grūtības iegūt precīzu informāciju ne vien iepriekš minēto iemeslu dēl attiecībā uz agrīno dziesmu autoru anonimitāti, bet arī tāpēc, ka daḷa dziesmu nepieder akadēmiskajai mūzikai. Profesionālie komponisti savas dziesmas fiksē notīs: sākumā rokrakstā, vēlāk bieži vien arī iespiestu nošu veidā un mūzikas ierakstā. Savukārt sadzives mūzikā vai dziesminieku vidē tas nemaz nav pašsaprotami, un dažreiz dziesmas ilgu laiku nemaz netiek pierakstītas nošu rakstā un pazīstamas tikai šaurā zinātāju lokā. Ne velti Maksims Strunskis, Berlīnē dzīvojošs ārsts, kurš apkopojis līdz šim zināmās

\footnotetext{
${ }^{10}$ Losberga, M. 1905. gada revolucionārās dziesmas Latvijā, 116. lpp.

${ }^{11}$ Dziesmu krājums jauktiem un vīru koriem. Čelsija, Masačūsetsa, ASV: 1912. RTMM, Valentīna Bērzkalna kolekcija, inv. Nr. 776412.

${ }^{12}$ Laicens, L. Strādnieku dziesmas. Kreisā Fronte, 1928, Nr. 4, 16. lpp.

${ }^{13}$ Bērziña, V. Jānis Zālītis. Rīga: Liesma, 1978, 241. lpp.
} 
dziesmas ar Edvarta Virzas dzeju, secinājis: "Tas bija darbietilpīgs, patiesībā detektīvdarbs, jo informācijas avoti izrādījās l,oti sadrumstaloti."14

Lai sastādītu tālāk skatāmo sarakstu, izmantotas iespiestās notis, izdotie ieraksti, nošu rokraksti Rakstniecības un mūzikas muzeja krājumā, Latvijas Nacionālās bibliotēkas katalogs, interneta resursi un iespieddarbi, piemēram, 2017. gadā izdotais dzejoḷu krājums "Par spīti grūtiem laikiem" ar komponistu sarakstu, kuri sacerējuši dziesmas ar Veidenbauma vārdiem. ${ }^{15}$ Saraksts neietver dziesmas ar anonīmu, marginālu autoru melodijām vai arī mūsdienu ritmiskās mūzikas kompozīcijas, kur izmantota tikai kāda frāze no Veidenbauma, kā arī pāris dziesmu, kuru teksti kḷūdaini tiek piedēvēti Veidenbaumam, piemēram, "Es zinu, visi mani nievā”. Autoru vārdi sakārtoti alfabēta secībā.

\begin{tabular}{|c|c|c|}
\hline $\begin{array}{l}\text { Nr. } \\
\text { p. } k \text {. }\end{array}$ & $\begin{array}{c}\text { Komponista vārds un } \\
\text { uzvārds }\end{array}$ & $\begin{array}{c}\text { Dziesmas nosaukums (iekavās pie dažām dziesmām - } \\
\text { tekstam izmantotā dzejoḷa sākums) }\end{array}$ \\
\hline 1. & Māris Balaško & Lai iet, $k \bar{a}$ iet \\
\hline 2. & Ints Birzkops & Ej un dzenies tik pēc naudas \\
\hline 3. & Stanislavs Bogdanovs & Domāju es domas dzilas \\
\hline 4. & Arvīds Cellers & Iedzer, brāli \\
\hline 5. & Georgs Dovgjallo & Kulsos es \\
\hline 6. & Rihards Dubra & Ziemas svētkos (Rau, svētku eglìte) \\
\hline 7. & Alnis Dūdums & Gan labāki ies; Iedzer, brāli \\
\hline 8. & Andris Dzenītis & $\begin{array}{l}\text { Ists filozofs nav pesimists; Daudz cilvēku; Rožainie laiki; } \\
\text { Upes malu liepas èno }\end{array}$ \\
\hline 9. & Raimonds Eizenšmits & Nost reiz skumïbu metǐšu \\
\hline 10. & Oḷggerts Grāvītis & Mosties, mosties reiz, svabadais gars \\
\hline 11. & Aleksandrs Jasjukevičs & Rau, svētku eglite tik koši \\
\hline 12. & Pāvils Johansons & Kā gulbji balti padebeši iet; Ej un dzenies \\
\hline 13. & Imants Kalniņš & Jau ziediem rotātas plavas \\
\hline 14. & Alfrēds Kalniņš & Kā gulbji balti padebeši iet; Jau ziediem rotātas pḷavas \\
\hline 15. & Kārlis Kažociņš & Kā gulbji \\
\hline 16. & Andris Kivičs & $\begin{array}{l}\text { Domāju es domas dzilas; Dzīve zalı; Kam tỉk dzìvot, tas lai } \\
\text { dzìvo; Nost reiz metišs skumibu tumšo; Par spitti grūtiem lai- } \\
\text { kiem; Virs zemes nav taisnibas, dūrei tik spēks; Viss ir joks }\end{array}$ \\
\hline 17. & Juris Krūze & $\begin{array}{l}\text { Dažs visu mūžz; Es atminos rožainos laikus; Es domāju, ka } \\
\text { pasaule;; Pa laukiem jau ziedonis dvašo; Sniegs no laukiem } \\
\text { projām steidz; Upes malu liepas èno }\end{array}$ \\
\hline
\end{tabular}

\footnotetext{
${ }^{14}$ Strunskis, M. Edvarta Virzas dzeja latviešu mūzikā. Jaunā Gaita, 2013, Nr. 273, 25. lpp.

${ }^{15}$ Veidenbaums, E. Par spīti grūtiem laikiem. Rīga: Jumava, 2017. 50. lpp.
} 


\begin{tabular}{|c|c|c|}
\hline $\begin{array}{l}\text { Nr. } \\
\text { p. k. }\end{array}$ & $\begin{array}{c}\text { Komponista vārds un } \\
\text { uzvārds }\end{array}$ & $\begin{array}{c}\text { Dziesmas nosaukums (iekavās pie dažām dziesmām - } \\
\text { tekstam izmantotā dzejọ̣a sākums) }\end{array}$ \\
\hline 18. & Juris Kulakovs & 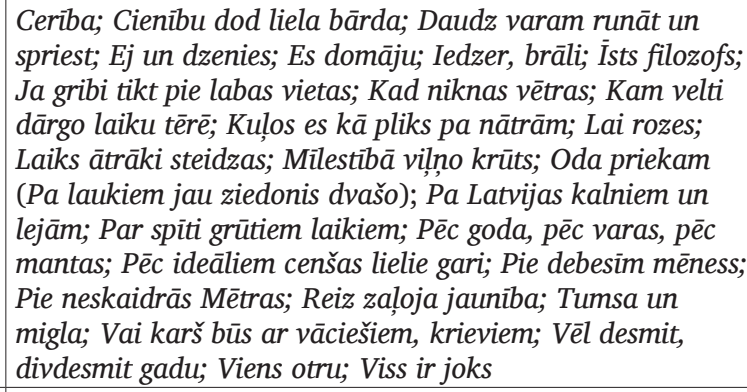 \\
\hline 19. & Jānis Liepkalns & Jau ziediem rotātas plavas \\
\hline 20. & Jānis Lūsēns & Nost skumjïbu \\
\hline 21. & Jānis Norvilis & Nost reiz skumïbu metī̌u tumšo; Tumsa un migla \\
\hline 22. & Jānis Ozoliņš & Mosties, mosties reiz, svabadais gars \\
\hline 23. & Valdemārs Ozoliņš & Eglìte (Rau, svētku eglìte) \\
\hline 24. & Eduards Patvaldnieks & Kā gulbji balti padebeši iet \\
\hline 25. & Raimonds Pauls & Ziemassvētkos (Rau, svētku eglite) \\
\hline 26. & Lauma Reinholde & $\begin{array}{l}\text { Svētku eglìte (Rau, svētku eglìte); Pa ielām dubl̦ainām; Jau } \\
\text { ziediem rotātas pl̦avas }\end{array}$ \\
\hline 27. & Jānis Reinholds & Mosties, mosties reiz, svabadais gars \\
\hline 28. & Visvaldis Sanders & Ziemassvētku dziesma (Rau, svētku eglïte) \\
\hline 29. & Ansis Sauka & Kā gulbji balti padebeši iet \\
\hline 30. & Jānis Sieriņš & Ej un dzenies \\
\hline 31. & Uldis Stabulnieks & Rau, svētku eglite \\
\hline 32. & Harijs Užāns & Ej un dzenies tik pēc naudas; Pielīdējs; Tauta \\
\hline 33. & Egons Valters & Iedzer, brāli \\
\hline 34. & Ainars Vepers & Ej un dzenies tik pēc naudas \\
\hline 35. & Ivars Vīgners & Es atceros bijušos laikus; Jau ziediem rotātas plavas \\
\hline 36. & Marğeris Zariņš & Kā gulbji balti padebeši iet \\
\hline 37. & Jānis Zālītis & Kā gulbji balti padebeši iet \\
\hline 38. & Āris Ziemelis & Pa ielām dubl̦ainām \\
\hline
\end{tabular}

Svarīgākais, kas atklājas, pārskatot izmantotos tekstus, ir tas, ka komponēta gandrīz puse dzejoḷu. Daži dzejoḷi pat vairākkārt, tādējādi dziesmu kopskaits ir pāri par aston, kuras apzinājis Strunskis, redzams, ka Veidenbauma dzeja komponēta daudz. Abos gadījumos dziesmu skaits ir vairāki desmiti, taču Virzas radītās dzejas apjoms ir daudz lielāks nekā Veidenbaumam. Skaitliskam salīdzinājumam nosacīti 
var kalpot arī izdevums "Dzejnieks Hugo Krūmiņš mūzikā", ${ }^{16}$ kurā apkopotas 28 dziesmas un viena kantāte ar Hugo Krūmiṇa tekstu. Arī Krūmiṇa dzeja ir mazskaitlīga un maz komponēta, bet Veidenbauma dzejoḷu kopums komponēts krietni vairāk. Tādējādi var secināt, ka par Veidenbauma dzejas izmantošanas biežumu mūzikā liecina ne tik daudz komponēšanas gadījumu skaits, cik tas, ka komponēta tik liela daḷa no viņa dzejoliem.

\section{Dziesmu un to tekstu pētniecība Latvijā}

Vērtējumi par latviešu komponistu dziesmām publicistikā lasāmi jau kopš 19. gadsimta beigām, sākot ar Jurjānu Andreju un Straumes Jāni. Muzikologu pētījumos galvenokārt analizēts atsevišḳu kompozīcijas pan̄ēmienu un izteiksmes līdzekḷu lietojums, bet dažos gadījumos pievērsta uzmanība arī dzejas un mūzikas sakarībām. Guna Goluba pārlūkojusi Viḷa Plūdoṇa dzejas izmantojumu latviešu komponistu klasiḳu daiḷradē, ${ }^{17}$ par Ojāra Vācieša dzejas interpretācijām latviešu ̄zikā rakstījusi Inga Zakamennija, ${ }^{18}$ par Rabindranata Tagores dzeju latviešu mūzikā - Inga Godunova. ${ }^{19}$ Dzintra Erliha, izstrādājot savu Lūcijai Garūtai veltīto promocijas darbu, pētījusi dzejas motīvus komponistes solo dziesmās. ${ }^{20}$ Ilma Grauzdina analizējusi dzejas un mūzikas mijiedarbi Jāzepa Vītola kordziesmās. ${ }^{21}$ Gundega Šmite vairākās publikācijās un promocijas darbā meklējusi atbilstošākas metodes, kā analizēt mūzikas un teksta mijiedarbes jaunās koncepcijas novatoriskajā 21. gadsimta latviešu kormūzikā. ${ }^{22}$

Muzikologu pētījumos dziesma aplūkota galvenokārt kā akadēmiskās mūzikas žanrs, vienīgi Inga Zakamennija savā darbā par Ojāra Vācieša dzeju latviešu mūzikā pieminējusi, ka šĩ dzeja izmantota arī rokmūzikā - Imanta Kalniņa ciklā "Balādes par Matisonu". ${ }^{23}$ Taču dziesmas ir daudzveidīgas, akadēmiskajai mūzikai piederīga ir tikai viena daḷa - koncertmūzika (pārsvarā dziesmas balsij ar pavadījumu un kora dziesmas). Savukārt citu žanru dziesmas (ziņgeses, šlāgeri, sadzīves dziesmas u. c.) mazāk pilda koncertmūzikai raksturīgās estētiskās funkcijas, bet vairāk sociālas, komunikatīvas vai citas, kuru muzikoloǵiskās pētniecības

${ }^{16}$ Dzejnieks Hugo Krūmiņš mūzikā. Sast. O. Grāvītis. Rīga: Musica Baltica, 2001.

${ }^{17}$ Goluba, G. Vịla Plūdoṇa dzeja latviešu komponistu klasiḳu daiļradē. Diplomdarbs. Rīga: LVK, 1955.

${ }_{18}$ Zakamennija, I. Ojāra Vācieša dzeja latviešu mūzikā. Diplomdarbs. Rīga: JVLVK, 1986.

${ }^{19}$ Godunova, I. Tagores dzeja latviešu mūzikā. Diplomdarbs. Rīga: JVLVK, 1990.

${ }^{20}$ Erliha, Dz. Dzejas motīvi Lūcijas Garūtas solodziesmās. Grām.: Mūzikas akadēmijas raksti VI. Sast. B. Jaunslaviete. Rīga: JVLMA, 2009.

${ }^{21}$ Grauzdiña, I. Vēlreiz par dzejas un mūzikas mijiedarbi Jāzepa Vītola kordziesmās. III starptautiskā praktiski zinātniskā konference "Māksla un müzika kultūras diskursā". Rēzekne: RTA, 2014.

22 Šmite, G. Mūzikas un teksta mijiedarbes jaunās koncepcijas latviešu kormūzikā (21. gadsimta pirmā dekāde). Promocijas darbs. Rīga: JVLMA, 2013; Šmite G. Jaunās verbālā teksta traktējuma tendences 21. gadsimta pirmās dekādes latviešu kormūzikā. Grām.: Latviešu mūzikas kods. Sast. I. Šarkovska-Liepiña. Rīga: Musica Baltica, 2014. 172.-192. lpp.

${ }^{23}$ Zakamennija, I. Ojāra Vācieša dzeja latviešu mūzikā. 
uzmanības laukā nav vai arī ir margināli. Zīmīgs šajā ziṇā ir Jāṇa Torgāna raksts par dziesmu "Dažu skaistu ziedu”, ${ }^{24}$ kurā viņš raksturo sadzīves muzicēšanu kā nemateriālu kultūras vērtību un akadēmiskajai izpētei it kā paralēlu versiju, kas ietver tās vietu un jēgu sabiedrībā, cilvēka un sabiedrības pieredzi, atmiṇu, pārdzīvojumu un vērojumu mutvārdu tradīciju. Viṇš konstatē, ka, no vienas puses, "mūzikas vēstures rakstības praksē pārsvarā ir materiālais, objektīvais: nošu raksts, programmas un afišas, preses atsauksmes u. tml.", no otras puses, raugoties uz sadzīves muzicēšanu, jāatzīst, ka "šai jomai tāpat ir savas vispārējas, sociālas un vēsturiskas saskarsmes un likumības". ${ }^{25}$

Jāpiebilst, ka dziesmas, kas dēvētas par revolucionārām vai politiskām dziesmām un drīzāk piederīgas neakadēmiskajai mūzikai, tomēr ir pētītas kā Latvijas mūzikas vēstures parādība. Lija Krasinska atbilstoši padomju ideoloǵiskajām nostādnēm par to rakstījusi nodaḷā "1905. gada revolūcija un mūzika" grāmatā "Latviešu mūzikas vēsture", ${ }^{26}$ no cita skatpunkta par to izteicies Imants Sakss rakstā "Par politisko dziesmu" žurnālā "Jaunā Gaita". ${ }^{27}$ Bet apjomīgāko pētījumu šajā jomā izstrādājis Guntis Šmidchens, folklorists un valodnieks, asociētais profesors un Baltijas studiju programmas vadītājs Vašingtonas Universitātē ASV. Savā monogrāfijā "Dziesmu vara" vinš izmantojis vēstures, antropoloǵijas, folkloras, muzikoloǵijas un pat sociālās psiholoǵijas zināšanas, lai stāstītu par neatkarības centieniem 80.-90. gados Latvijā, Igaunijā un Lietuvā un Baltijas dziesmoto revolūciju. ${ }^{28}$

Savu zīmogu muzikolog̣ijas attieksmei pret dziesmas žanra pētniecību uzlikusi arī padomju ideologija un cenzūra, jo tā visvairāk skāra tāda veida mūziku, kas sacerēta ar tekstu, īpaši dziesmas. Sevišķi rūpīgi tika cenzētas dziesmas izklaides mūzikā, jo tās bija populārākas, tika cenzēti arī citi izklaides mūzikas žanri. Daiļrunīgs piemērs ir padomju laika attieksme pret klasisko opereti, kurai piedēvēja tā saukto buržuāzisko nacionālismu. ${ }^{29}$ Tas netiešā veidā atturēja no šādas mūzikas pētniecības, kas vadošās ideolog̣ijas ieskatā bija ar apšaubāmu vērtību. Pēdējos gados redzams, ka jaunās paaudzes pētnieki ir brīvi no šìs ietekmes un pētniecībā saistoši kḷūst arī šlāgeri vai rokmūzika. Tomēr kopumā vērojams, ka informāciju par neakadēmisko žanru dziesmām parasti cenšas apkopot nevis mūzikas zinātnieki, bet sociologi, antropologi, mūzikas aprakstnieki, mīḷtōài un interesenti, piemēram, kolekcionārs Atis Gunivaldis Bērtiņš savā grāmatā "Latviešu skaņuplašu vēsture". ${ }^{30}$ Tā kā dziesmas ar Veidenbauma dzeju ir žanriski dažādas, tad interesantas tendences atrodamas, tās ne vien muzikoloǵiski analizējot, bet arī skatot kontekstā ar procesiem sabiedrībā.

\footnotetext{
${ }^{24}$ Torgāns, J. Dažu skaistu ziedu un citas lappuses latviešu kultūras vēsturē. Grām.: Mūzikas akadēmijas raksti IX. Sast. B. Jaunslaviete. Rīga: JVLMA, 2012. 125.-137. lpp. ${ }^{25}$ Turpat, 125. lpp.

${ }^{26}$ Vītolin̦š, J.; Krasinska, L. Latviešu mūzikas vēsture. Rīga: Liesma, 1972. 325.-329. lpp.

${ }^{27}$ Sakss, I. Par politisko dziesmu. Jaunā Gaita, 1988, Nr. 170, 28.-30. 1pp.

${ }^{28}$ Šmidchens, G. Dziesmu vara. Rīga: Mansards, 2017.

${ }^{29}$ Kaijaks, J. Mazliet par sevi un operetes teātri. Rīga: Pētergailis, 2007. 53. 1pp.

${ }^{30}$ Bērtiņš, A. G. Latviešu skaṇuplašu vēsture. Rīga: Vesta-LK, 2015-2017.
} 


\section{Populārākās dziesmas ar Veidenbauma vārdiem}

Viens no zīmīgiem raksturlielumiem, runājot par dziesmām ar Veidenbauma vārdiem, ir tas, kā sabiedrība tās uztver. Pārskatot dažādus informācijas avotus, var gūt ieskatu, kuras dziesmas kādā laikposmā bijušas vairāk iemīḷtotas. Veidenbauma dzejoḷi izplatās tautā 19. gadsimta beigās, 20. gadsimta sākumā, kad Latvijā briest 1905. gada revolūcija. Liepājas strādnieks J. Driega savās atmiṇās to pieminējis, raksturojot laiku pēc 1882. gada:

Parādījās arī Ed. Veidenbauma dzejas manuskriptā, tās tika desmitiem eksemplāros pārrakstītas un laistas apkārt: tik daudz lasītas, deklamētas un dziedātas, ka es gandrīz visas pat tagad no galvas atminos. ${ }^{31}$

Atmin̄ās par 1905. gada revolūciju bieži pieminēts, ka mītiņos un demonstrācijās dziedāta dziesma "Mosties, mosties reiz, svabadais gars", ka Veidenbauma dzejas bijušas pārrakstītas vai visās apcietināto revolucionāru kladēs un burtnīcās. Lilija Limane, pētot 1905. gada revolucionāru cietumnieku burtnīcas, secinājusi:

Īpašā statusā iekḷuvis E. Veidenbaums (7 dzejoḷi Andersona, J. Locina un Šlapa burtnīcās), kuru bieži izvēlas par vadmotīvu, kaut pēc skaita dzejoḷu nav l,oti daudz. ${ }^{32}$

Acīmredzot tieši šā dzejoḷa saturs ar aicinājumu uz sacelšanos rezonē ar revolucionāro noskan,ojumu, un tāpēc dzejolis "Mosties, mosties reiz, svabadais gars" tolaik kḷūst tik populārs gan kā deklamācija, gan dziesmas teksts.

Citāda noskaṇa ir Veidenbauma dzejolī "Domāju es domas dziḷas", kurš dziesmas veidolā izplatīts 20. gadsimta sākumā. Andrejs Upīts 1927. gadā pat paudis nožēlu, ka tas nepelnīti ir pazīstamākais no Veidenbauma veikuma:

Patlaban gan "tautā" liekas palikusies vēl tikai Veidenbauma pazīstamā dziesmiṇa "Domāju es domas dziḷas" - to pa lauku ceḷiem bḷauj dzērāji, ap pulksten četriem no rīta no zaḷumballēm mājup streipuḷodami. Protams, tiem nav daḷas gar dziesmas autoru, viņa vārdu tie pat dzirdējuši nav. ${ }^{33}$

Taču šì dziesmiṇa ar nezināma autora melodiju ir liecība par to, cik l,oti dzīvotspējīgas sadzìves mūzikā ir vienkāršas, rezignācijas pilnas skumju izpausmes un, Veidenbauma lakoniskajā, patiesīgajā dzejā izteiktas, dziesmās skan vēl šodien.

${ }^{31}$ Driega, J. Atmiņas. Proletariskā revolūcija Latvijā: I. Strādnieku šķiras partijas sākotne. L.K.P. vēstures materiali. [Pleskava]: Spartaks, 1924. 41. lpp.

${ }^{32}$ Limane, L. 1905.-1907. gada revolucionāru cietuma burtnīcas. Grām.: Informācija, revolūcija, reakcija: 1905-2005 = Information, Revolution, Reaction, 1905-2005. Rìga: Latvijas Nacionālā bibliotēka, 2005. 63.-69. lpp.

${ }^{33}$ Upìts, A. Eduarda Veidenbauma dzìve un darbi. Domas, 1927, Nr. 7, 119. lpp. 
Par iemīḷtōāko kora dziesmu ar Veidenbauma dzeju kḷuvusi 1918. gadā Kārḷa Kažocina sacerētā dziesma "Kā gulbji". Par to liecina kaut vai tas, ka tā četras reizes iekḷauta Vispārējo Dziesmu svētku repertuārā: VII Dziesmu svētkos (1931), VIII Dziesmu svētkos (1933), XVI Dziesmu svētkos (1973) un XXI Dziesmu svētkos (1993). Arī mūsdienās, kaut sabiedrības muzikālā gaume ir l,oti fragmentēta, to cilvēku uztverē, kuri dzied koros vai klausās klasisko latviešu kormūziku, tieši Kažociņa dziesma ir pazīstamākā Veidenbauma dzejas interpretācija mūzikā.

Padomju gados, pateicoties Rīgas Kinostudijas filmai "Kā gulbji balti padebeši iet" (1956) ar Marğera Zarina mūziku, plaši pazīstama kḷūst viṇa dziesma ar tādu pašu nosaukumu. Filmas stāstā par latviešu revolucionāru izmantotas Sarkanās armijas komisāra Jāṇa Fabriciusa biogrāfijas epizodes, un šā satura dēl filma un mūzika pēc neatkarības atgūšanas publikai vairs neškiet tik pievilcīga. Otra padomju gados plašāk pazīstamā kora dziesma ar Veidenbauma vārdiem Imanta Kalniṇa “Jau ziediem rotātas plavas” (1981) - piedzīvojusi savu lielāko popularitāti Atmodas laikā, kad dziesminieku dziedātās Kalniṇa dziesmas lielisko melodiju un tekstu dẹl bija klausītāju iemīḷtotas, tā bija iekḷauta XXII Vispārējo Dziesmu svētku repertuārā 1998. gadā.

Jura Kulakova dziesma "Reiz zaļoja jaunība" saglabājusi klausītāju mīlestību nemainīgi kopš sacerēšanas 1987. gadā. Tā ir viena dạ̦a no Kulakova cikla "Septiņarpus dziesmas ar Eduarda Veidenbauma vārdiem" solistei un rokgrupai. Tomēr atšķirībā no pārējām cikla dziesmām tā ir tipiska sentimentāla zinğge un rakstīta tikai balsij ar gitāras pavadījumu. Autors to pašironiski uzskata par "pusdziesmu", tāpēc arī ciklam devis tādu savdabīgu nosaukumu. Šì ir pazīstamākā no minētā cikla dziesmām: 1988. gada "Mikrofona aptaujā" ieguvusi trešo vietu un iekḷauta arī Latvijas simtgades iemīḷotāko latviešu dziesmu izlasē, kas veidota 2018. gada aptaujā portālā "Izdziedam 100".

Kas padara tieši šìs dziesmas populāras, nav viennozīmīgi atbildams, taču viens no pašiem svarīgākajiem faktoriem ir dziesmas teksta saturs, pati Veidenbauma dzeja. Jo tieši tā iedvesmojusi komponistus sacerēt atbilstošas melodijas, un bieži vien tekstā paustais ir izšķirošs, lai dziesma iemantotu tautas mīlestību. Rakstniecības un mūzikas muzeja 2013. gadā veiktajā aptaujā uz jautājumu "Kas, jūsuprāt, ir Imanta Kalniṇa mūzikas popularitātes pamatā?" respondentu visvairāk izvēlētā atbilde bija - "izmantotie dziesmu teksti” (33,6 \% no visiem aptaujātajiem). Tad, kad sabiedrībai aktuāls dzejoḷa saturs apvienojas ar atbilstošu melodiju, rodas dzīvotspējīga vai pat īpaši iecienīta dziesma. Šajā zin̄ā Veidenbauma dzejas izmantojums centrējas it kā divās gultnēs. Vienā ir protests un dumpinieciskums, par kura kvintesenci var pieņemt dzejoli "Mosties, mosties reiz, svabadais gars", tā popularitātes kulminācija - 1905. gada revolūcijas laiks. Šis pats teksts būtu bijis aktuāls arī Trešās atmodas laikā, ja vien padomju laika institūcijas nebūtu izmantojušas Veidenbauma dumpinieciskumu, lai radītu par viņu sev izdevīgu priekšstatu kā par revolucionāru dzejnieku, un šis traucējošais ideologisiskais uzslān,ojums zūd tikai pamazām. Mūsdienās, kad izaugusi paaudze, kas ir brīva no padomju laika domāšanas klišejām, aicinājums "Mosties, mosties reiz, svabadais gars" jauniem cilvēkiem atkal škiet fascinējošs, un 2017. gadā šo tekstu savai mūzikai izmantojusi, piemēram, grupa "Kapakmens" un vairākas citas ritmiskās mūzikas grupas. 
Otra gultne noskaņas ziṇā ir romantisms dažādās izpausmēs. Šajā ziṇā nepārspēta virsotne ir "Kā gulbji balti padebeši iet". To komponējuši vismaz septiņi autori: Jānis Zālītis 1905.-1906. gadā, Alfrēds Kalniņš 1917. gadā, Kārlis Kažociņš 1918. gadā, Marğeris Zarinšs 1956. gadā, Eduards Patvaldnieks 50.-70. gados trimdā ASV, Pāvils Johansons Zviedrijā 1987. gadā, Ansis Sauka 1997. gadā. Šis dzejolis populārs ne tikai kā dziesma, škiet, ka sabiedrības uztverē tas zināmā mērā personificē Veidenbauma dzejas būtību. Par to liek domāt Latvijas Universitātes Literatūras, folkloras un mākslas institūta organizētā akcija "Skandē Veidenbaumu" 2017. gadā: dalībnieku visvairāk ierunātais dzejolis izrādījās "Kā gulbji balti padebeši iet". Pieminēšanas vērts arī dzejoḷa izmantojums Latvijas Bankas izlaistajā divu monētu komplektā par godu Veidenbaumam 2017. gadā: uz monētām attēloti mākoṇi un frāzes "Tiem vēlētos es līdza tālu skriet" un "Tur tālumā, kur ziemas nepazīst".

Dzejolis "Rau, svētku eglīte" gan komponēts skaitliski tikpat daudz (Rihards Dubra, Aleksandrs Jasjukevičs, Valdemārs Ozoliņ̌s, Raimonds Pauls, Lauma Reinholde, Visvaldis Sanders, Uldis Stabulnieks), taču šā teksta izvēli vairāk noteikusi vajadzība sacerēt dziesminuu Ziemassvētkiem. Arī žanriskais risinājums te ir daudz šaurākā amplitūdā, salīdzinot ar teksta "Kā gulbji balti padebeši" interpretācijām, veidotām tik dažādiem atskan,otāju sastāviem - gan kā solo dziesma ar pavadījumu (Jānis Zālītis, Alfrēds Kalniņš), gan kā kora dziesma jauktajam korim (Kārlis Kažociņš, Eduards Patvaldnieks) vai sieviešu korim (Ansis Sauka), gan kā kino mūzika (Marǵeris Zariņš) un kā rokdziesma (Pāvils Johansons).

Saprotamā kārtā nav statistikas par dziesmu popularitāti tik ilgā laikposmā, kādā radušās dziesmas ar Veidenbauma dzeju, tomēr no atbildēm dažādās aptaujās un intervijās un citiem avotiem var novērot tendenci, ka dziesmas likteni ietekmē sabiedrības noskaņojums. Ja sabiedrībā dominē pārmaiņu gaidas un neapmierinātība ar dzīvi, tad lielāku rezonansi gūst dzeja un dziesmas protesta noskan̄ās ("Mosties, mosties reiz, svabadais gars"). Laikos, kad dzīves plūdums ir līdzenāks, iemīlotas ir dziesmas, kas pauž romantiskas noskaņas: ilgošanos pēc laimes ("Kā gulbji balti padebeši iet"), smeldzi par aizgājušo jaunību ("Reiz zaḷoja jaunība"), rezignāciju par neizdevušos dzīvi ("Domāju es domas dziḷas").

\section{Kāpēc komponisti izvēlas dziesmām Veidenbauma dzeju?}

Galvenais, kas rosina mūzikas autoru sacerēt dziesmu ar kādu tekstu, ir saturs: stāsts, vēstījums dziesmas tekstā. Pieredzējušais dziesmu tekstu autors Guntars Račs vairākkārt atzinis: "Vārdam ir milzīga nozīme un tāpat stāstam, par ko tad dziesma īsti ir." ${ }^{34}$ Veidenbauma dzejas izmantojums mūzikā izceḷas ar to, ka tas aizsācies tik sen, - viṇa dzejas vēstījums piesaistījis komponistus pirms simts gadiem un nav apsīcis līdz pat mūsdienām. Tas turpinās, kaut daudzu viṇa laikabiedru - atzītu dzejnieku - vārsmas jau sen novecojošas.

${ }^{34}$ Ezera, D. Ar saknēm Liepājas bruǵī. Saruna ar Guntaru Raču. Latvijas Avīze, 2015, 12. marts. 
Komponistus, tāpat kā Veidenbauma dzejas lasītājus, visus šos ilgos gadus piesaista tas, kas viņš runā par pašiem galvenajiem cilvēka dzīves jēgas jautājumiem, dara to emocionāli, lakoniskā un bieži vien pat ironiskā izteiksmē. Veidenbauma dzejā apbrīnojami organiski līdzās pastāv intelekts un romantiska pasaules uztvere. Viṇa dzeju izvēlas par dziesmu tekstiem arī tāpēc, ka dzejas valoda ir mērḳtiecīga, bez izpušksojumiem un sentimenta. Taču sākotnēji tieši valoda un izteiksme izrādījusies vairāk piemērota sadzìves dziesmām ar pielāgotām melodijām, mazāk - profesionālu komponistu dail̦radei. Pirmajiem profesionālajiem latviešu komponistiem Veidenbauma tiešā, dažbrīd pat sadzīviskā dzejas valoda sākotnēji škitusi pārāk raupja. Ne velti dzejnieka draugs Edvards Treimanis-Zvārgulis, Veidenbauma dzīvi un darbus aprakstot, paudis par to savu neizpratni:

Tepat būtu jāatzīmē: neviens no latviešu komponistiem nav komponējis neviena vienīga Veidenbauma dzejoḷa. Pate tauta ir spiesta tiem melodijas piegudrot kā, piemēram, dzejolim "Domāju es domas dzil̦as”. Kā tas saprotams? Kālab mūsu komponisti, kuri pat dažu sīku garinu ievēro, tik auksti iet garām geniālajam Veidenbauma? Vai arī tas priekš viniiem būtu par spēcīgu un atklātu? ${ }^{35}$

Latviešu mūzikas pamatlicēji - Jurjānu Andrejs, Jāzeps Vītols, Emīls Dārzinšs savām dziesmām Veidenbauma dzeju nav izmantojuši. Tā ienāk latviešu profesionālajā mūzikā tad, kad laikmeta norišu priekšplānā izvirzās tautas likteņa apdraudētība, kontrasts starp sapṇu, ilgu pasauli un skarbo realitāti, ko tik spilgti dzejnieks izteicis dzejolī "Kā gulbji balti padebeši iet”. Nav nejaušība, ka Jānis Zālìtis savu dziesmu ar šo tekstu raksta, briestot 1905. gada revolūcijas vētrainajiem notikumiem, Alfrēds Kalniņš un Kārlis Kažociņš - 1917. un 1918. gadā, kad jaundibinātajai Latvijas valstij pastāvēšanas tiesības vēl jāizcīna Neatkarības kara kaujās. Zīmīgi, ka neviens no minētajiem komponistiem nav izmantojis dzejoḷa pēdējās četras rindas, un tikai 1956. gadā Marğeris Zariņš padomju laika filmai domātajā dziesmā komponē visu tekstu. Tas parāda, kā mainījusies mūzikas estētika. Muzikologs Arnolds Klotiņš atgādina, ka gadsimta sākumā tāda veida teksti dēvēti par "fabriku dzeju": "[T]ā sauktā fabriku dzeja vai tās elementi tolaik vēl visumā skaitījās profesionālai mūzikai nepiemēroti, nekomponējami." 36

Tādējādi saprotams, kāpēc pirmspadomju laika komponisti Veidenbauma tekstu izmantošanā bijuši samērā atturīgi. Vēlākos gados Jānis Ozoliņ̌̌ un Oḷgerts Grāvītis komponējuši dzejoli "Mosties, mosties reiz, svabadais gars”, taču šīs dziesmas jāuzlūko drīzāk kā nodeva padomju ideologijas prasībām, savukārt Imants Kalniņš un Ivars Vīgners atraduši Veidenbauma dzejā iespējas stilizēt seno laiku naivo romantismu (abi komponējuši "Jau ziediem rotātas pḷavas", un Ivars Vīgners vēl arī "Es atceros bijušos laikus").

\footnotetext{
${ }^{35}$ Treimanis-Zvārgulis, E. Eduards Veidenbaums savā dzīvē un darbos. Grām.: Veidenbaums, E. Kopoti raksti. Valmiera: P. Skrastina apgāds, 1907. 103. lpp.

${ }^{36}$ Klotinšs, A. Alfrēds Kalniņš. Rīga: Zinātne, 1979. 210. lpp.
} 
Tomēr savu īstenāko interpretu Veidenbauma dzeja sastop rokmūziḳa Jura Kulakova personā 80. gados. Muzicējot ansamblī "Menuets", Kulakovs, sapratis, ka vēlas "lielākas kaislības un lielāku ekspresiju", ${ }^{37}$ izveido pats savu grupu "Pērkons" ar mērķi radīt kvalitatīvu latviešu rokmūziku, izmantojot labu dzeju. Te nu Veidenbauma dumpinieciskums un skarbums īsti vietā. Jau 1980. gadā Kulakovs ar dziesmām "Mefistofeḷa padomi", kur izmantoti Veidenbauma teksti, piedalījies Latvijas Valsts universitātes Politiskās dziesmas festivālā, bet uz lielāku darbu viṇu iedvesmojis Veidenbauma muzeja apmeklējums Kalāčos 1987. gadā. Būdams konservatorijas students, Kulakovs tur piedalījies sarīkojumā no Jauno komponistu apvienības, saticis tolaik jaunos dzejniekus Māri Melgalvu, Klāvu Elsbergu, Inesi Zanderi, Egīlu Zirni, skanējušas dziesmas un dzeja. Pēc tam arī radies populārais Kulakova cikls "Septiņarpus dziesmas ar Veidenbauma vārdiem", kas veltīts grupas "Pērkons" solistei, dziesminiecei Ievai Akuraterei. Tajā izmantoti dzejoli "Tumsa un migla", "Viss ir joks", "Pēc goda, pēc varas, pēc mantas", "Reiz zal̦oja jaunība", "Viens otru", "Es domāju", "Vēl desmit, divdesmit gadu" un "Kad niknas vētras". Šis dziesmu cikls padomju varas gados netiek izdots oficiāla ieraksta veidā, tas izplatās magnetofona lentes ierakstā. Cikla popularitāti veicina arī tā atainojums Latvijas TV muzikālajā videofilmā "Bet vilciens brauc" (1987, režisors Arvīds Babris), kur filmējušies Ieva Akuratere, Juris Kulakovs Veidenbaumam līdzīgā tēlā un amatierteātra aktieri. Daudziem TV skatītājiem tolaik un droši vien arī mūsdienu interneta lietotājiem šì filma likusi iepazìt un novērtēt Veidenbauma dzeju.

Juris Kulakovs arī turpmākajos gados pievērsies Eduardam Veidenbaumam atsevišksās dziesmās, bet jauns cikls top 2008. gadā - kantāte "Mīlestībā viḷno krūts". Tas ir jau apjomīgāks darbs, jo ietver 21 dziesmu - gan agrāk komponētas, gan tieši šai kantātei radītas. Arī atskan,otājsastāvu Kulakovs iecerējis vērienīgāku: te dzied solisti un koris "Gaudeamus", muzicē rokgrupa "Pērkons". No šìs kantātes dziesmām kori atseviški bieži vien dzied titulkompozīciju "Mīlestībā viḷno krūts", kas komponēta klasiskā korāļfaktūrā vīru korim a cappella un veltīta "Gaudeamus" diriǵentam Ivaram Cinkusam. Eduarda Veidenbauma dzejas sakāpinātā ironija un citviet ilgu pilnais romantisms dod iespēju Jurim Kulakovam radīt mūziku ar teatrāliem stilizācijas pan̄ēmieniem, veidot spēcīgus kontrastus, miksējot rokmūzikai piemītošo dinamiku ar kamerstila liriku. Populārā dziesma "Reiz zalıja jaunība” ir ziņgées stilizācija un apliecina Jura Kulakova melodiḳa talantu. (Par ko jau latviešu klasiskās mūzikas pamatlicējs un ilggadējais kompozīcijas pedagogs Jāzeps Vìtols sacījis: "Konservatorijā es varu jums iemācīt rīkoties ar harmoniju un kompozīcijas tehniku, bet nekad to, kā būtu jāraksta spilgta melodija, šì lieta ir atkarīga no jūsu pašu talanta spējām un fantāzijas." ${ }^{38}$ )

Eduarda Veidenbauma dzejas interpretācijās nozīmīgs ir Andra Dzenīša 2017. gadā komponētais cikls "Četras Eduarda Veidenbauma dziesmas un veltījums". Tas radies kā pasūtījuma darbs un talantīgi veikts, sniedzot profesionāla komponista laikmetīgu skatījumu vokālās kamermūzikas žanrā uz Veidenbauma

${ }^{37}$ Dzenītis, A. Vēstījums un izteiksme. Mūzikas Saule, 2008, Nr. 6, 30. lpp.

${ }^{38}$ Vērina, S. Jāzeps Vìtols - komponists un pedagogs. Rīga: Avots, 1991. 241. lpp. 
dzeju. Komponists izmantojis tekstus "Īsts filozofs nav pesimists", "Daudz prātīgu cilvēku pasaulē dzīvo", "Es atminos rožainos laikus" un "Upes malu liepas ēno", starp pēdējām divām iestarpinot dzejnieka Jāṇa Rokpeḷna triptihu "Eduards Veidenbaums" kā veltījumu dzejnieka traǵiskajai dzīvei. Krāsainību un nianšu kontrastus, ko Kulakovs spēj radīt ar rokmūzikas līdzekḷiem, Dzenītis veido, izmantojot tikai dziedātāja balsi un klavieru partiju. Atšḳirībā no daudziem amatieriem, kuri lielākoties izmanto Veidenbauma dzeju, lai sacerētu dziesmas strofu formā (bieži vien shēmā: pants - piedziedājums, kas atkārtojas), šie profesionālie komponisti realizē tādu dzejas muzikālās interpretācijas principu, kas jūtīgi reaǵē uz teksta īpatnībām, un necenšas to iespiest kādā muzikālā shēmā. Andris Dzenītis par to izteicies intervijā sakarā ar šā cikla komponēšanu:

\begin{abstract}
Mani interesē dzejas izkārtojums, strofas, pantu garums, uzsvari, neregularitāte vairāk nekā tradicionālās ritma pēdās balstīti piemēri. Tādēḷ vismaz manas mūzikas kontekstā nācās meklēt izeju un risinājumu, kā būt klātesošam šajā vēstījumā. Varbūt kḷuvu nedaudz eklektisks, te ir viss - gan šansons, gan asas stikla lauskas, gan bezgalīgs, velkošs lēnums. Tas bija interesants piedzīvojums un iespēja arī pašam skaniski pieskarties Veidenbauma emocijām. ${ }^{39}$
\end{abstract}

Izvēloties tekstus dziesmām, Dzenītis centies nepārspīlēt ar Veidenbauma dzejai piedēvēto pesimismu, jo viņu iedvesmojis dzejā paustais jūtu patiesums:

[C]entos drīzāk atlasīt tos Veidenbauma dzejoḷus, kuros vairāk jūsmots par šīs pasaules daili. Grūtsirdīgāka dziesma ir "Daudz cilvēku", bezcerīgi melanholiska - "Es atceros rožainos laikus", taču par "Īsts filozofs nav pesimists" un "Upes malu liepas ēno" pats esmu pārsteigts, cik melodiskas, reizē naivas, taču no sirds patiesas tās izaugušas. Likās, ka šie četri dzejoḷi labi ataino visu Veidenbauma dzejas kvintesenci, taču gribējās arī tādu kā skatu no malas, tāpēc kā komentāru Veidenbauma dzīvei izmantoju man l,oti tuvā dzejnieka un drauga literatūrā Jāṇa Rokpeḷna dzejoli "Veidenbaums" - skarbas paša Veidenbauma izjūtas îsi pirms atvadīšanās no šìs pasaules. Tas arī kḷuvis par cikla centru, balsta kolonnu, balstītu citā laiktelpā. ${ }^{40}$

Līdzās Veidenbauma dzejas saturam un izteiksmei ir vēl kāds faktors, kas piesaista komponistus, - viṇa dzejas muzikalitāte. To pirmais uzsvēris Juris Kulakovs, piemēram, intervijā 2008. gadā viņ̌̌ atgādina, ka Veidenbaums spēlējis vijoli: "Ne velti viña dzeja, lai cik skarba brīžiem būtu, ir skanīga - viena no muzikālākajām fonētiskā zin̄ā." ${ }^{41}$ Kas nosaka to, ka dzeja ir muzikāla, tas ir l,oti interesants

\footnotetext{
${ }^{39}$ Brokāne, L. Mūzika kā teksta komentārs. Intervija ar komponistu Andri Dzenīti. Pieejams: http://rmm.lv/2017/10/muzika-ka-teksta-komentars-intervija-ar-komponistu-andridzeniti/ [sk. 10.03.2019.]

${ }^{40}$ Turpat.

${ }^{41}$ Tamuḷeviča, Dž. Veidenbaums Kulakova garā. Diena, 2008, 12. nov.
} 
un vēl pētāms jautājums. Tomēr līdz šim latviešu autori ir vienojušies vismaz par dažiem parametriem - fonētiskā labskanība un teksta iekšējā melodija, piemēram, Oḷǵgerts Grāvītis rakstījis Hugo Krūmiṇa dzejas sakarā:

Nav šaubu, ka tieši Hugo Krūmiņa poēzijas klasiski skaidrā ritmika, savdabīgā, it kā zemdegās slēptā, bet reizē labi saklausāmā iekšējā melodika uzjundī lasītājā - komponistā muzikālos risinājumus. ${ }^{42}$

Par to domājuši arī paši dzejnieki, piemēram, Sergejs Moreino:

[P]ietiekams dzejas teksta muzikalitātes nosacījums ir tā ārpuskonteksta patstāvība, saprotamība cilvēkam bez lielām priekšzināšanām dzejā, ja vien šis cilvēks nav ar "biezām ausīm". ${ }^{43}$

Savukārt Inese Zandere atzīstas, ka, rakstot dzeju, viņa bieži vien to pie sevis izdzied:

Apsverot savu dzejoḷu attiecības ar mūziku, atklāju kaut ko pretrunīgu - tātad droši vien patiesu: manos dzejoḷos dominē redzes tēli un vieliskuma atveidi valodā, savukārt formu diktē skaņa. ${ }^{44}$

Veidenbaumu droši vien iespaidojusi arī sadzīves muzicēšana, jo 19. gadsimta beigās latvieši vairāk nekā šodien spēlēja un dziedāja, būdami labi amatnieki, paši būvēja vijoles un ērǵeles un citus mūzikas instrumentus. Līdzīgi arī Veidenbaums ar vijoli savam priekam dažkārt spēlējis vienkāršas melodijas. Sava loma bijusi arī garīgajām dziesmām, kas viṇa ǵimenē dziedātas regulāri. Par Veidenbauma muzikalitāti bērnībā liecinājis Treimanis-Zvārgulis: "Eduards līdz savam skolas laikam ar sajūsmību lasīja svētos rakstus un mācījās, un dziedāja garīgās dziesmas." 45

Tādējādi var secināt, ka Eduarda Veidenbauma neparastās personības mantojums dzejā cauri vairāk nekā simts gadiem joprojām piesaista ne vien lasītājus, bet arī komponistus, rosinot viṇa tekstus interpretēt mūzikā. ${ }^{46}$ Viṇa dzejas pievilcību veido tēlu loks, izteiksme un muzikalitāte - pietiekami daudz komponentu, lai piesaistītu gan dažādu stilu mūzikas autorus, gan dotu impulsus radìt dziesmas ḷoti plašā žanriskā amplitūdā no zingóes līdz Dziesmu svētku kopkora dziesmai vai izsmalcinātai mūsdienu vokālajai kamermūzikai.

${ }^{42}$ Dzejnieks Hugo Krūmiņš mūzikā, 3. lpp.

${ }^{43}$ Moreino, S. Starway to Heaven. Müzikas Saule, 2008, Nr. 4, 7.-9. lpp.

${ }^{44}$ Zandere, I. Rakstīt vajag tā, kā dzied. Mūzikas Saule, 2008. Nr. 4, 10.-11. lpp.

45 Treimanis-Zvārgulis, E. Eduards Veidenbaums savā dzīvē un darbā, 10. lpp.

${ }^{46}$ 2017. gadā tapa jauns projekts: Veidenbaums. Vaidi un gaidi (2017). Naba Music. Par to plašāk: https://nabamusic.bandcamp.com/album/veidenbaums-vaidi-un-gaidi-2017 [sk. 30.06.2020.] - par šo norādi paldies muzikologei Ilzei Šarkovskai-Liepinai. 


\section{Eduards Veidenbaums's poetry as a catalyst for musical creations}

\section{Ligita Ašme}

The numerous events held to celebrate Veidenbaums's $150^{\text {th }}$ anniversary demonstrate the appeal of his poetry to contemporary people. Many events were organized around the songs set to his poetry. Both previously composed and new compositions were sung with unprecedented passion as an encouragement to reconsider the relationship between Veidenbaums's poetry and its musical interpretation.

When reviewing songs set to Veidenbaums's poetry, one faces insufficient information for two reasons. Firstly, the authors of older melodies are unknown, and secondly, amateur songs are not always recorded. However, even with the amount of information available, it is possible to get some overview of these songs.

It can be concluded that Veidenbaums's poetry, considering such a small number of poems, is proportionally much composed - almost every second poem is set to music. A series of poems are transferred into songs not once or twice, but even several times, for example, such a popular poem White clouds are passing like swans (Kā gulbji balti padebeši iet) is set to music at least seven times.

Besides, the analysis of chronology of songs based on Veidenbaums's poetry requires the examination of the entire history of Latvian music, because this period lasts over more than a hundred years. Hence, the analysis reveals not only how and why Veidenbaums's poetry is used in songs, but also the general dynamics of the relationship between lyrics and melodies during the evolvement of the song genre. It is an additional component of the landscape, which is reflected in the set of songs based on Veidenbaums's poetry.

Keywords: Veidenbaums, song genre, interpretation of poetry, poetic musicality, 'schlager' or popular songs. 